\title{
Essential and toxic elements in commercial microalgal food supplements
}

\author{
Piotr Rzymski ${ }^{1}$ D · Joanna Budzulak ${ }^{1} \cdot$ Przemysław Niedzielski $^{2} \cdot$ Piotr Klimaszyk $^{3} \cdot$ Jędrzej Proch $^{2} \cdot$ Lidia Kozak $^{2}$. \\ Barbara Poniedziałek ${ }^{1}$
}

Received: 23 July 2018 / Revised and accepted: 29 October 2018 / Published online: 13 November 2018

(C) The Author(s) 2018, corrected publication 2019

\begin{abstract}
Arthrospira spp. (known commercially as Spirulina) and Chlorella spp., valued for their evidence-based nutritional and bioactive properties, are cultivated for the purpose of production of food supplements for worldwide distribution. However, the quality and safety of the final product depends on culturing and manufacturing conditions. The present study investigated the content of toxic elements (As species, Al, Cd, Hg, Ni, Pt, Pb, Cr (VI), rare earth elements) and minerals (Ca, $\mathrm{Co}, \mathrm{Cr}, \mathrm{Cu}, \mathrm{Fe}, \mathrm{K}, \mathrm{Na}, \mathrm{Mg}, \mathrm{Mn}, \mathrm{P}$, $\mathrm{Zn})$ in Chlorella $(n=10)$ and Spirulina $(n=13)$ food supplements registered in the European Union. Considering the most common recommended daily dosage 3.0, supplementation with any of the studied product would contribute significantly to mineral intake, with the exception of Fe which was found at high but acceptable levels in both Spirulina and Chlorella formulas. The majority of products revealed agreement between factual mineral content and that declared on the label, the only exception being $\mathrm{Cu}$ content in Chlorella products found to be significantly higher (>130\%). All studied supplements were found to have $\mathrm{Cd}, \mathrm{Hg}$, and $\mathrm{Ni}$ levels much below safety limits, although selected ones were characterized by increased content of $\mathrm{Al}, \mathrm{Pb}$, and inorganic As. No hexavalent Cr was detected in the studied products. The study highlights that microalgal supplements can be safe for consumers if appropriate measures are taken to ensure consumer safety, although it underlines the continuous need to monitor these products in order to fully eliminate those of low quality.
\end{abstract}

Keywords Microalgal supplements $\cdot$ Spirulina $\cdot$ Chlorella $\cdot$ Mineral content $\cdot$ Contamination $\cdot$ Metals $\cdot$ Food safety $\cdot$ Food quality

\section{Introduction}

The market of food supplements is on the rise, with increasing numbers of individuals interested in using these formulas for various purposes in Europe, the USA, and Asia. There is particular interest in targeting those products that are based on ingredients of natural origin (Kennedy 2005; Hirayama et al.

Electronic supplementary material The online version of this article (https://doi.org/10.1007/s10811-018-1681-1) contains supplementary material, which is available to authorized users.

Piotr Rzymski

rzymskipiotr@ump.edu.pl

1 Department of Environmental Medicine, Poznan University of Medical Sciences, Rokietnicka 8, 60-806 Poznań, Poland

2 Department of Analytical Chemistry, Adam Mickiewicz University, Poznań, Poland

3 Department of Water Protection, Adam Mickiewicz University, Poznań, Poland
2008; Bailey et al. 2013). Within this group, supplements that are based on microalgal biomass are not only gaining economic attention, but at the same time, their bioactive properties are being extensively explored using complementary research models: in vitro and in in vivo experiments, and randomized, placebo-controlled clinical trials involving different groups of patients (Panahi et al. 2016; de la Jara et al. 2018). These products use biomass of cyanobacteria belonging to the genera of Arthrospira (known commercially as Spirulina), Nostoc, and the former "Aphanizomenon," and green algae representing the genera Haematococcus, Dunaliella, and Chlorella (Pulz and Gross 2004). The greatest market success has been achieved by Spirulina and Chlorella formulas, with the main cultivation plants located in the USA and Asia, particularly in China, the current leader in global microalgal biomass production (García et al. 2017).

Spirulina- and Chlorella-based products are known to be a rich source of proteins, fatty acids, pigments, minerals (e.g., calcium, magnesium, phosphorus, zinc, copper, and iron), digestive and restriction enzymes, and selected vitamins such as bioavailable forms of $\mathrm{B}_{12}, \mathrm{C}$, and $\mathrm{E}$ (Buono et al. 2014; Wells 
et al. 2016). As evidenced using clinical trials, both supplements reveal promising bioactive properties encompassing immunomodulatory, antihypertensive, antilipidemic, and hypoglycemic effects (Nielsen et al. 2010; Kim et al. 2016; Juszkiewicz et al. 2018). This not only advocates the role of these products as functional foods but also supports their potential therapeutic use. For example, supplementation with Spirulina has been shown to decrease the viral load and increase CD4 cells in HIV-infected patients, modulate lipid metabolism, control appetite and promote weight loss in obese subjects (Zeinalian et al. 2017), and increase ability to resist mental and physical fatigue in men (Johnson et al. 2016), while Chlorella supplementation reveals a protective antioxidant effect in smokers (Panahi et al. 2013), may be efficiently used in adjunctive therapy for depressive disorders (Panahi et al. 2015), and to improve glycemic status in patients with non-alcoholic fatty liver disease (EbrahimiMameghani et al. 2017).

There are no doubts that a biomedical exploration of the properties of Spirulina and Chlorella imparts a reliability to these products and helps to strengthen their market. It is, however, of high importance to ensure the safety of the final commercial product. Arthrospira spp. and Chlorella spp. are not known to produce any toxic compounds and their safety is well established (Buono et al. 2014; Wells et al. 2016; García et al. 2017). Nevertheless, one should note that cultivation of microalgae for scientific purposes may vary from that conducted on a large, commercial scale. Over recent years, the quality of selected microalgal supplements available in trade has been put in doubt due to the detection of cyanotoxins, e.g., neurotoxic anatoxin-a and $\beta$ methylamino-l-alanine, hepatotoxic microcystins resulting from alterations to culture purity and the co-occurrence of toxigenic species such as Microcystis aeruginosa (Vichi et al. 2012; Manali et al. 2017; Roy-Lachapelle et al. 2017). There have also been reports of increased levels of aluminium, lead, and inorganic arsenic, possibly as a consequence of the unsuitable location of cultivation ponds and the use of chemical methods to harvest biomass (Papazi et al. 2010; Hedegaard et al. 2013; Rzymski et al. 2015). However, some individuals, particularly those suffering from autoimmune disorders, can be specifically susceptible to microalgal supplements (Lee and Werth 2004), and it is likely that the occurrence of adverse effects such as diarrhea, nausea, abdominal pain, and skin rash reported after consumption of these products (Rzymski et al. 2015; Rzymski and Jaśkiewicz 2017) may have origins in their altered and imperfect quality. Therefore, it is imperative that the content of (potentially) toxic elements in these formulas be investigated, yet updated information in this regard is limited (Al-Dhabi 2013; Hedegaard et al. 2013; Rzymski et al. 2015).

Recent studies have shown that various food supplements such as multi-ingredient formulas can reveal high discrepancies between the factual nutritional value and that which is declared on the product label (Brandon et al. 2014; Niedzielski et al. 2016; Poniedziałek et al. 2018). Large-scale cultivation of microalgae for food production that most often employs raceway pond systems is prone to various environmental conditions, mitigation of which may be challenging. The nutritional value of produced biomass can be influenced by the presence and availability of certain compounds in cultivation medium. It is therefore of interest to examine whether the content of minerals declared on the labels of commercial microalgal supplements matches their factual levels within the accepted margin.

The aim of the present study was to assess the content of toxic metals ( $\mathrm{Al}, \mathrm{Cd}, \mathrm{Hg}, \mathrm{Ni}, \mathrm{Pb}$ ), hexavalent chromium, arsenic species, rare earth elements (REEs), and essential macro- and trace elements $(\mathrm{Ca}, \mathrm{Co}, \mathrm{Cr}, \mathrm{Cu}, \mathrm{K}, \mathrm{Mg}, \mathrm{Mn}, \mathrm{Mo}$, $\mathrm{Na}, \mathrm{Se}, \mathrm{Fe}, \mathrm{Zn}$ ) in Spirulina and Chlorella food supplements originating from different world regions and registered for distribution in the European Union. The determined levels of minerals were compared to those declared on the product labels.

\section{Materials and methods}

\section{Food supplements}

A total of 13 Spirulina-based and 10 Chlorella-based food supplements were randomly purchased from online stores. The inclusion criteria were official registration as a food supplement, country of origin declared on the label, powder or tablet form. The general characteristics of the studied products are given in Table 1. The following number of Spirulina and Chlorella products declared the content of the studied minerals on the label: $\mathrm{Ca}, 9$ and $10 ; \mathrm{Cu}, 9$ and $8 ; \mathrm{K}, 9$ and $10 ; \mathrm{Mg}$, 10 each; Mn, 11 and 9; $\mathrm{Fe}, 11$ and 10; Se, 3 and 1; Na, P, and $\mathrm{Zn}, 1$ each 1; Cr and Mo, 1 and $0 ; \mathrm{Co}$, none.

\section{Total element content analysis}

The whole batch of each supplement was ground, thoroughly mixed, and weighed. Afterwards, $0.50 \mathrm{~g}$ of each formula was digested in $8 \mathrm{~mL}$ of suprapure $\mathrm{HNO}_{3}$ in closed Teflon vessels using the microwave sample digestion system Mars 6 (CEM, USA). The digestion procedure consisted of two steps: ramp to temperature $180{ }^{\circ} \mathrm{C}$ for $20 \mathrm{~min}$ and hold at $180{ }^{\circ} \mathrm{C}$ for $30 \mathrm{~min}$. After digestion, the solution was diluted to a final volume of $15 \mathrm{~mL}$ with ultrapure water obtained in the MilliQ system (Millipore, USA). Each supplement was prepared in triplicate.

The content of essential macroelements $(\mathrm{Ca}, \mathrm{Mg}, \mathrm{K}, \mathrm{Na}$, and $\mathrm{P})$ and trace elements $(\mathrm{Co}, \mathrm{Cr}, \mathrm{Cu}, \mathrm{Mn}, \mathrm{Mo}, \mathrm{Se}, \mathrm{Fe}$, and $\mathrm{Zn}$ ), toxic metals ( $\mathrm{Al}, \mathrm{Cd}, \mathrm{Ni}, \mathrm{Hg}$ and $\mathrm{Pb}$ ), light REEs 
Table 1 General characteristics of the studied group of microalgal food supplements (S, Spirulina; Ch, Chlorella)

\begin{tabular}{|c|c|c|c|c|}
\hline Supplement & Declared species & Country of origin & Form & $\begin{array}{l}\text { Daily dose recommendations } \\
{[\mathrm{g}]}\end{array}$ \\
\hline S-1 & Spirulina sp. & China & Powder & 4.0 \\
\hline $\mathrm{S}-2$ & Spirulina sp. & China & Powder & 4.0 \\
\hline $\mathrm{S}-3$ & Spirulina sp. & China & Powder & 1.5 \\
\hline S-4 & Spirulina platensis & China & Powder & Not given \\
\hline S-5 & Spirulina sp. & Taiwan & Powder & 3.0 \\
\hline S-6 & Spirulina Pacifica & USA & Tablets & 3.0 \\
\hline S-7 & Arthrospira platensis & China & Powder & 3.0 \\
\hline S-8 & Spirulina platensis & China & Tablets & 3.0 \\
\hline S-9 & Spirulina sp. & China & Tablets & $2.0-3.0$ \\
\hline S-10 & Spirulina maxima & China & Tablets & 1.5 \\
\hline S-11 & Spirulina sp. & China & Tablets & 2.0 \\
\hline S-12 & Spirulina sp. & China & Tablets & 2.0 \\
\hline S-13 & Spirulina sp. & India & Powder & 5.0 \\
\hline Ch-1 & Chlorella sp. & China & Tablets & 3.0 \\
\hline Ch-2 & Chlorella vulgaris & Taiwan & Tablets & 3.0 \\
\hline Ch-3 & Chlorella pyrenoidosa & Japan & Tablets & 3.0 \\
\hline $\mathrm{Ch}-4$ & Chlorella sp. & India & Tablets & Not given \\
\hline Ch-5 & Chlorella sp. & China & Powder & $2.0-3.0$ \\
\hline Ch-6 & Chlorella sp. & China & Powder & Not given \\
\hline $\mathrm{Ch}-7$ & Chlorella pyrenoidosa & China & Powder & 3.0 \\
\hline Ch-8 & Chlorella vulgaris & China & Powder & 3.0 \\
\hline Ch-9 & Chlorella vulgaris & Portugal & Powder & 0.6 \\
\hline Ch-10 & Chlorella vulgaris & China & Tablets & 3.0 \\
\hline
\end{tabular}

(LREEs: Ce, Eu, Gd, La, Nd, Pr, Sc, Sm), and heavy REEs (HREEs: Dy, Er, Ho, Lu, Tb, Tm, Y, and Yb) was determined using the inductively coupled plasma optical emission spectrometer Agilent 5110 ICP-OES (Agilent, USA). ICP commercial analytical standards (Romil, England) were applied for the calibration. The following common instrumental parameters were used for determination of all elements: RF power $1.2 \mathrm{~kW}$, plasma gas (argon) flow $12 \mathrm{~L} \mathrm{~min}^{-1}$, nebulizer gas (argon) flow $0.7 \mathrm{~L} \mathrm{~min}^{-1}$, axial plasma observation. The applied wavelengths $(\mathrm{nm})$, limits of detection $\left(\mathrm{mg} \mathrm{kg}^{-1}\right)$, and levels of instrumental precision (\%) for each determined element are summarized in Table S1. Traceability was checked using the standard reference materials: CRM S-1, CRM NCSDC (73349), CRM 2709, CRM 405, and CRM 667. The recovery (80-120\%) was acceptable for all the elements determined.

\section{Arsenic speciation analyses}

To determine the inorganic and organic As content, $1.00 \mathrm{~g}$ of each supplement (homogenized by rubbing and sieving through a $0.02-\mathrm{mm}$ sieve) was placed in a glass flask containing $10 \mathrm{~mL} 1 \mathrm{M}$ phosphoric acid and several drops of Triton100 and extracted in an ultrasonic bath $(30 \mathrm{~min}$ at ambient temperature). Next, the solution was filtered using a paper filter (the filter was washed by $200 \mathrm{~mL}$ of water and $20 \mathrm{~mL}$ of phosphoric buffer). The $\mathrm{pH}$ of the solution was adjusted to $6-6.5$ by the addition of $10 \mathrm{~mol} \mathrm{~L}^{-1}$ solution of $\mathrm{NaOH}$, and finally, the solution was diluted to $20 \mathrm{~mL}$ with phosphate buffer. Each supplement was prepared in triplicate. The inorganic arsenic species, arsenite As (III) and arsenate $\mathrm{As}(\mathrm{V})$ in the acid extracts, were determined by HPLC-HG-ICP-OES immediately following the extraction procedure. The HPLC instrument was a liquid chromatograph (Shimadzu, Japan) with an anion-exchange column (Supelco, USA) LC-SAX1 (250 mm, $4.6 \mathrm{~mm}$ i.d.). The chromatographic run was isocratic at $3 \mathrm{~mL} \mathrm{~min}{ }^{-1}$ of phosphate buffer $\left(1 \mathrm{mmol} \mathrm{L}^{-1}\right.$ $\mathrm{Na}_{2} \mathrm{HPO}_{4}$ and $10 \mathrm{mmol} \mathrm{L}^{-1} \mathrm{KH}_{2} \mathrm{PO}_{4} \cdot 2 \mathrm{H}_{2} \mathrm{O}$ ) with an injection volume of $200 \mu \mathrm{L}$. PEEK (polyetheretherketone) tubing was inserted into a Tygon sleeve for transfer of the eluent from the LC column to the hydride generation unit. A spectrometer, model Agilent 5110 ICP-OES (Agilent, USA), with in-spray chamber generation of arsenic hydrides was used. For quantification, calibration curves based on the peak area for As (III) and $\mathrm{As}(\mathrm{V})$ were used. The final results were given as the mean concentration of As (III) and As(V); the remaining fraction (determined after ICP-OES analysis) was identified as organic As (Niedzielski et al. 2013). 


\section{Hexavalent chromium determination}

To determine $\mathrm{Cr}$ (VI), the colorimetric method with 1,5diphenylcarbazide was applied (Poniedziałek et al. 2018). For $2 \mathrm{~mL}$ of the sample extracted by $1 \mathrm{M}$ phosphoric acid, several drops of $0.5 \%(\mathrm{~m} / \mathrm{m})$ solution of diphenylcarbazide in acetone were added. Each supplement was prepared in triplicate. The eventual presence of a red-colored complex of $\mathrm{Cr}$ (VI) was determined spectrophotometrically at $540 \mathrm{~nm}$.

\section{Statistical analyses and calculations}

The results were analyzed using STATISTICA 10.0 software (StatSoft, USA). Because most of the data were not normally distributed (Shapiro-Wilk test, $p<0.05$ ), the non-parametric Mann-Whitney $U$ test was used for comparison in element content between Spirulina and Chlorella products. In all analyses, $p<0.05$ was considered as statistically significant.

The content of $\mathrm{Cd}, \mathrm{Hg}$, and $\mathrm{Pb}$ was with maximum allowance levels set for FS by the European Commission, 1.0, 0.1, and $3.0 \mathrm{mg} \mathrm{kg}^{-1}$, respectively (Commission Regulation (EC) No 629/2008: amending Regulation (EC) No 1881/2006). The total content of REEs was confronted with a maximum allowance threshold of $7.0 \mathrm{mg} \mathrm{kg}^{-1}$ dry weight (equivalent to $0.7 \mathrm{mg} \mathrm{kg}^{-1}$ fresh weight) set by China, the only country yet to regulate REEs in foodstuffs (SAC 2012). The contents of Al and $\mathrm{Ni}$ were related to their Tolerable Weekly Intake (TWI) set by the European Food Safety Authority (EFSA) at 1.0 and $0.0195 \mathrm{mg} \mathrm{kg}^{-1}$ body weight, respectively (EFSA 2008, 2015), assuming a daily consumption of $3.0 \mathrm{~g}$ of a supplement (the most common recommended dose, see Table 1) for a week by a 70-kg adult. Similarly, determined levels of essential elements were compared to Adequate Intake (AI) established by the EFSA (2017a). The following AI (per day) were assumed: $\mathrm{Ca}$, $950 \mathrm{mg}$; P, $550 \mathrm{mg}$; Mg, $350 \mathrm{mg}$; Na, not set; K, $3500 \mathrm{mg}$; Cu, $1.6 \mathrm{mg}$; Cr, not set; Co, not set; Mn, $3.0 \mathrm{mg}$; Mo, $0.065 \mathrm{mg}$; Fe, $11 \mathrm{mg}$; Se, $0.07 \mathrm{mg} ; \mathrm{Zn}, 11.7 \mathrm{mg}$. The determined content of Ca, $\mathrm{Cu}, \mathrm{K}, \mathrm{Fe}, \mathrm{Mg}$, and $\mathrm{Mn}$ was compared with that declared on the label. These minerals were selected because unlike Se, $\mathrm{Na}, \mathrm{P}$, $\mathrm{Zn}, \mathrm{Ce}, \mathrm{Mo}$, and $\mathrm{Co}$, these minerals were listed on the labels of the majority of the studied products. Seventy to $130 \%$ of declared value was considered as an acceptable margin (Niedzielski et al. 2016; Poniedziałek et al. 2018). In the case of As, the provisional Tolerable Weekly Intake (PTWI) established at a level of $15 \mu \mathrm{g} \mathrm{kg}^{-1}$ body weight (bw) of total As previously by the Joint FAO/WHO Expert Committee on Food Additives (JECFA 2012) has been disapproved by EFSA as inappropriate as adverse effects have been reported for exposures at lower levels of As. Instead, a benchmark dose lower confidence limit (BMDL01) was identified for cancers of the lung, skin, and bladder, as well as skin lesions, at a level of $0.3 \mu \mathrm{g} \mathrm{kg}^{-1} \mathrm{bw} \mathrm{day}{ }^{-1}$ for an increased cancer risk at $1 \%$ (EFSA 2009), and the content of As in the studied supplements was related to this value, assuming a daily consumption of $3.0 \mathrm{~g}$ of a product by a $70-\mathrm{kg}$ adult.

\section{Results}

\section{Toxic elements}

\section{Aluminium}

The mean $\pm \mathrm{SD}$ (median) content of $\mathrm{Al}$ amounted to $2155.6 \pm$ 1774.7 (1299.8) $\mathrm{mg} \mathrm{kg}^{-1}$ in Spirulina supplements and did not differ significantly from that found in Chlorella preparations-1732.8 \pm 1991.5 (1095.3) $\mathrm{mg} \mathrm{kg}^{-1}$ ( $p>0.05$, MannWhitney $U$ test). Three Spirulina and two Chlorella products whose weekly consumption at a daily dose of $3.0 \mathrm{~g}$ by a $70-\mathrm{kg}$ adult would exceed TWI for Al were identified (Fig. 1).

\section{Arsenic}

The As content was below detection limits $\left(0.1 \mathrm{mg} \mathrm{kg}^{-1}\right)$ in six Spirulina (46.1\%) and 5 Chlorella $(50.0 \%)$ products. In other supplements, the following order of As species was found: As organic $>\mathrm{As}(\mathrm{V})>\mathrm{As}$ (III), with sum of inorganic As ranging from $1.7-2.2 \mathrm{mg} \mathrm{kg}^{-1}$ in Spirulina and $2.3-2.7 \mathrm{mg} \mathrm{kg}^{-1}$ in Chlorella (Fig. 1). Considering the usual recommended daily dose of $3 \mathrm{~g}$ of supplement consumption, use of these products would lead to daily exposure to inorganic As at a level of 5.16.7 for Spirulina and 6.2-8.1 $\mu \mathrm{g}$ in the case of Chlorella. Such exposure would constitute respectively $24.3-31.9 \%$ and 29.5 $38.6 \%$ of BMDL01 assuming consumption by a 70-kg adult.

\section{Nickel}

The Ni content in Spirulina and Chlorella supplements was comparable and amounted to a mean $\pm \mathrm{SD}$ (median) of $1.52 \pm$ 0.72 (1.33) and $1.38 \pm 0.63$ (1.29) $\mathrm{mg} \mathrm{kg}^{-1}$, respectively. The highest content in the former group of products was $3.26 \mathrm{mg} \mathrm{kg}^{-1}$, and in the latter, $2.81 \mathrm{mg} \mathrm{kg}^{-1}$. Weekly supplementation with any studied supplement at a daily dose of $3.0 \mathrm{~g}$ by a $70-\mathrm{kg}$ adult would not exceed $40 \%$ of the established TWI for Ni, and in most cases, it was lower than $20 \%$ of the TWI (Fig. 1).

\section{Hexavalent chromium}

The Cr (VI) content was below the limit of detection $\left(0.01 \mathrm{mg} \mathrm{kg}^{-1}\right)$ in all studied samples.

\section{Cadmium}

The Cd content in all tested products fell much below the maximum allowance level $\left(1.0 \mathrm{mg} \mathrm{kg}^{-1}\right)$ set by the 


\section{Spirulina}

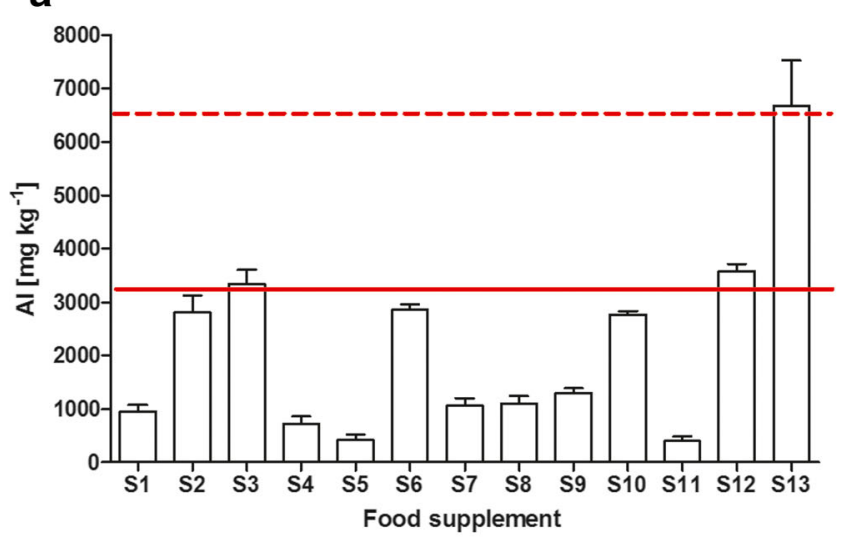

b

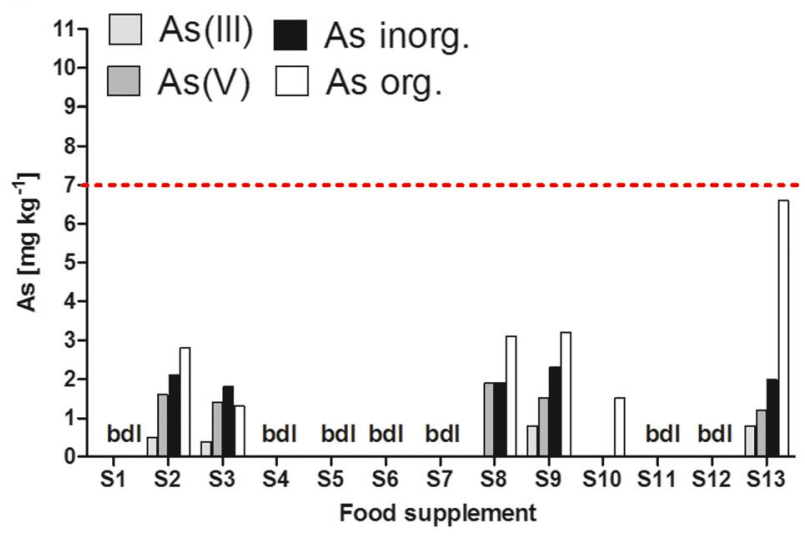

C

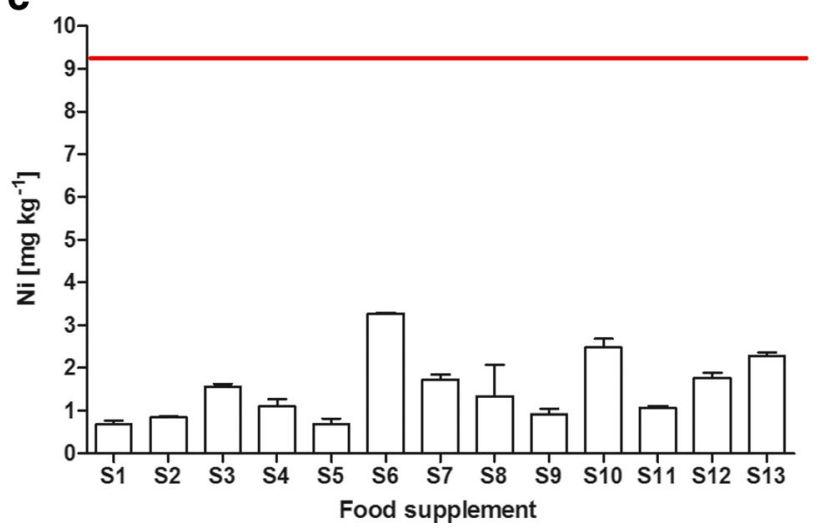

Fig. 1 The content (mean $\pm \mathrm{SD}$ ) of $\mathrm{Al}(\mathbf{a})$, As species (b), and $\mathrm{Ni}(\mathbf{c})$ in Spirulina (left column; $n=13$ ) and Chlorella (right column; $n=10$ ) in food supplements. The red line represents Tolerable Weekly Intake (TWI) set by the EC considering a weekly consumption at a daily dose of $3.0 \mathrm{~g}$ by a $70-\mathrm{kg}$ adult; the dashed red line represents Provisional Tolerable

European Commission (Fig. 2) and did not differ significantly between Spirulina- and Chlorella-based supplements ( $p>0.05$, Mann-Whitney $U$ test) with mean $\pm \mathrm{SD}$ (median) content amounting to $0.125 \pm 0.055(0.128)$ and $0.142 \pm 0.071$ (0.134) $\mathrm{mg} \mathrm{kg}^{-1}$, respectively.

\section{Chlorella}
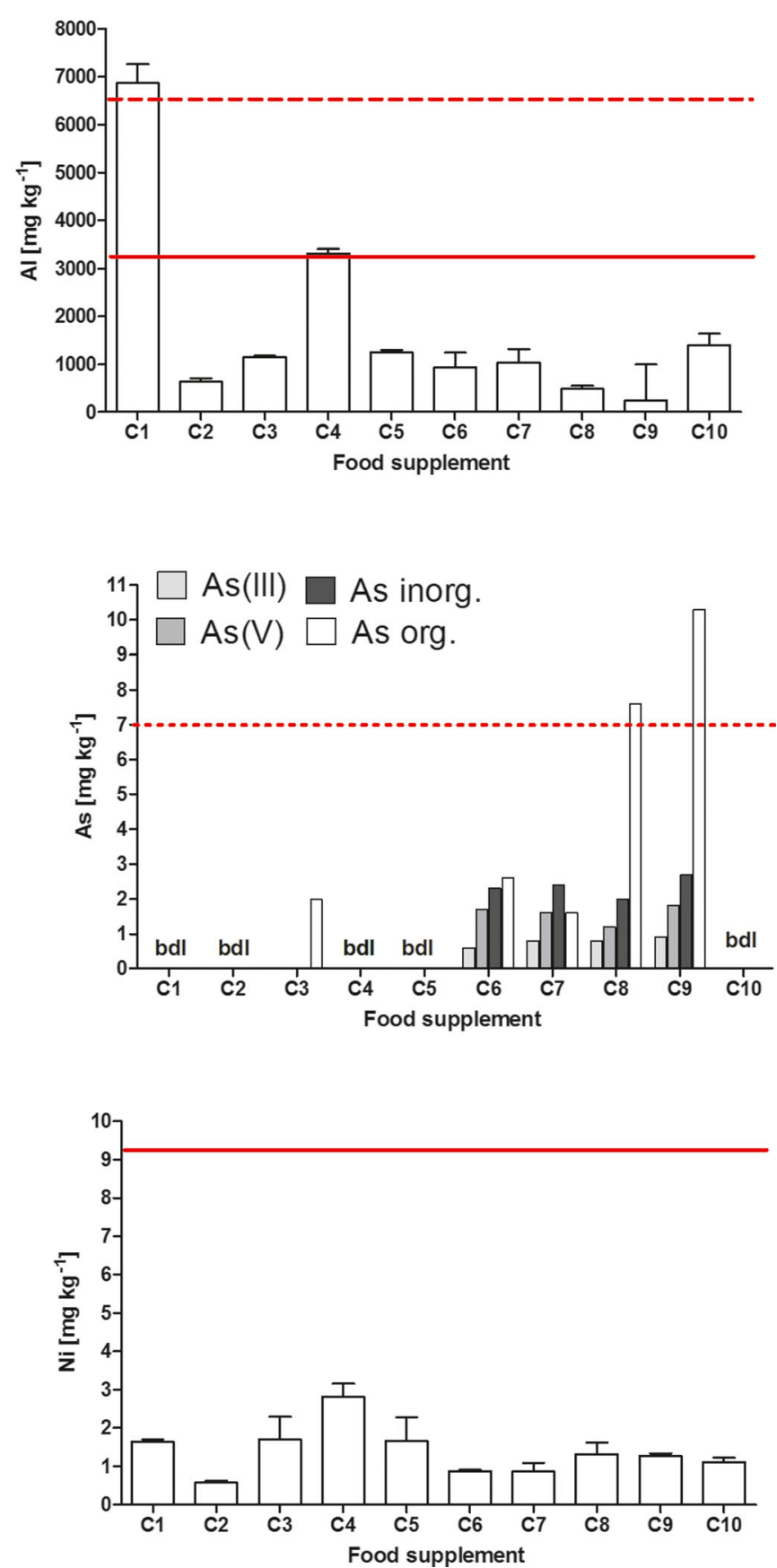

Weekly Intake (PTWI) set by the World Health Organization considering the same consumption as for TWI calculation. The dotted red line represents the Benchmark Dose Lower Confidence Limit (BMDL01) set for inorganic As at a consumption of $3.0 \mathrm{~g}$ of supplement by a $70-\mathrm{kg}$ adult. bdl, below detection limits

\section{Mercury}

$\mathrm{Hg}$ was detected in seven Spirulina (53.8\%) and eight Chlorella $(80.0 \%)$ food supplements at mean \pm SD (median) levels of $0.027 \pm 0.031(0.022)$ and $0.41 \pm 0.017(0.042)$, 


\section{a Spirulina}

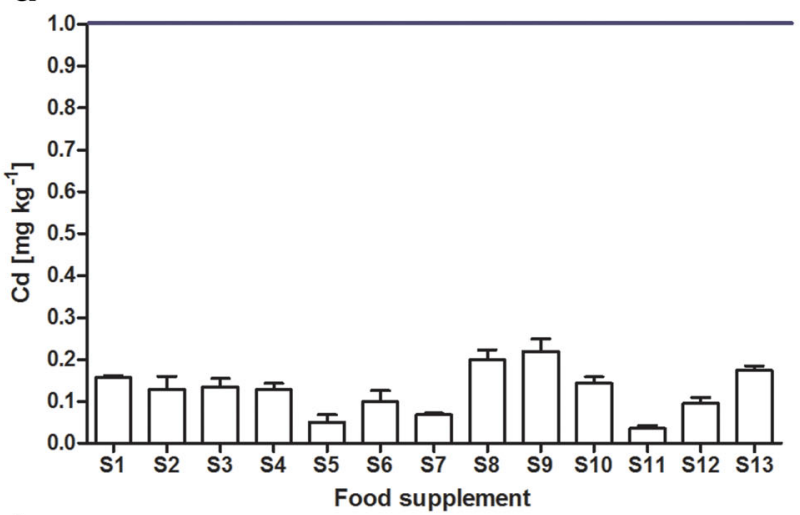

b

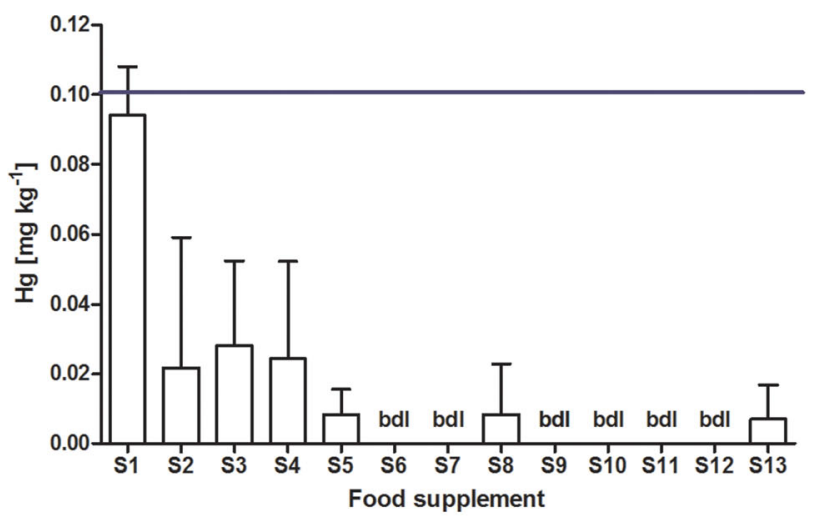

C

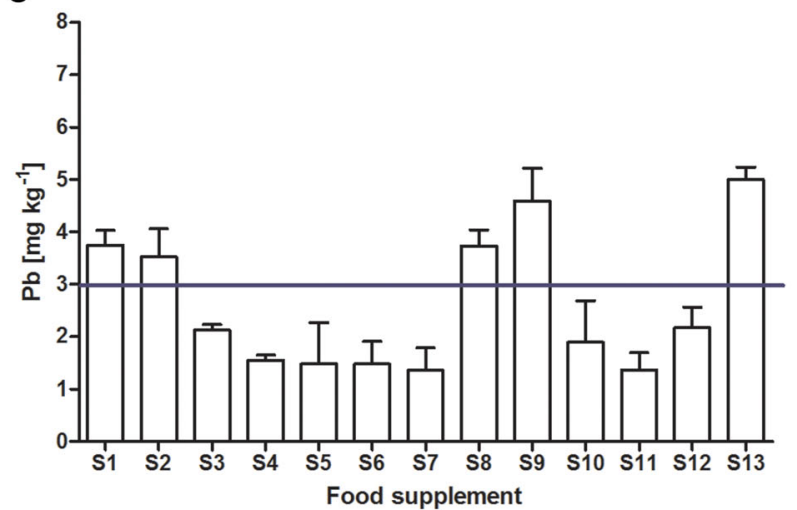

Chlorella
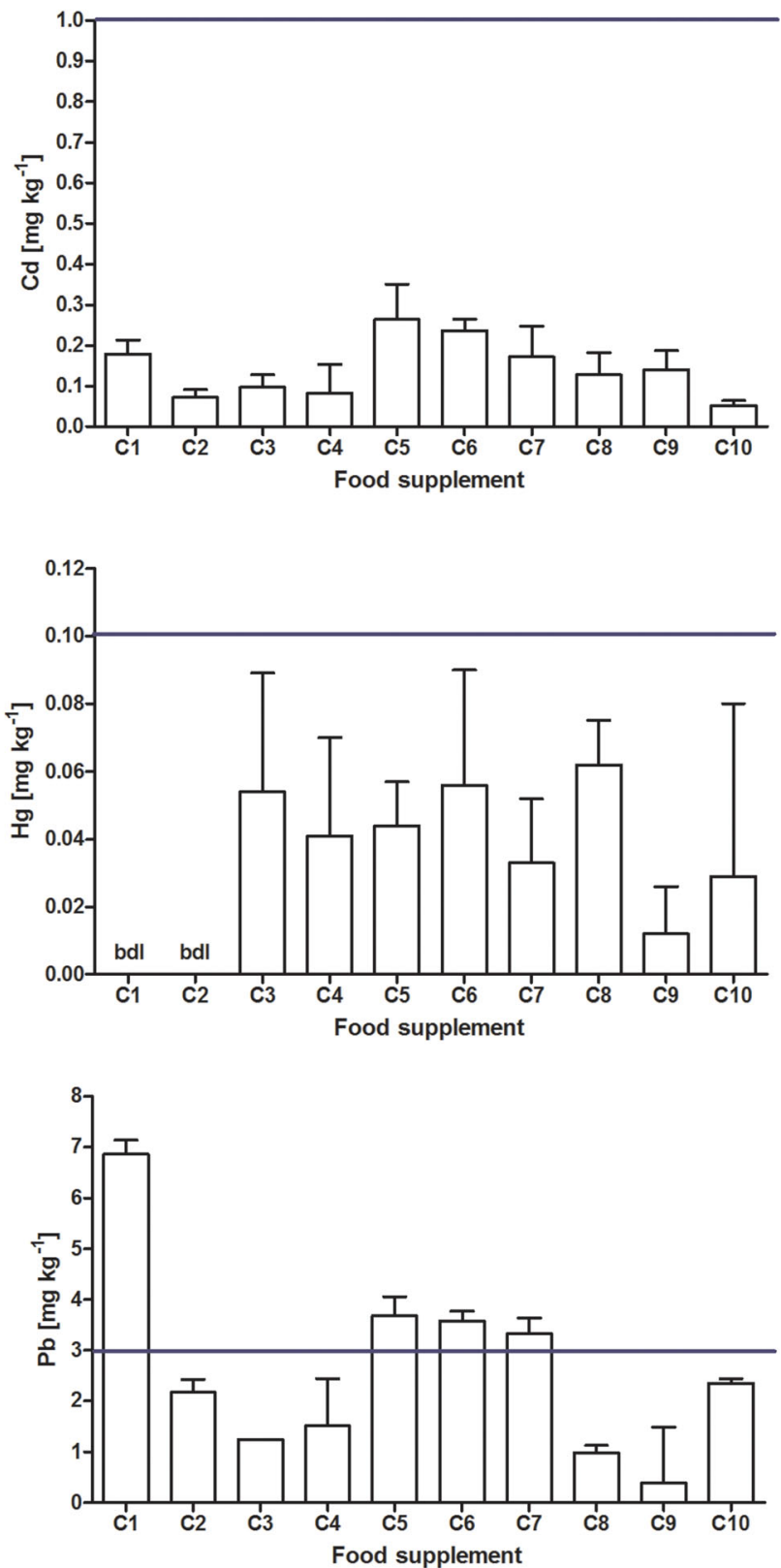

Fig. 2 The content (mean $\pm \mathrm{SD}$ ) of Cd (a), $\mathrm{Hg}(\mathbf{b})$, and $\mathrm{Pb}(\mathbf{c})$ in Spirulina (left column; $n=13$ ) and Chlorella (right column; $n=10)$ food supplements. The blue line represents maximum allowance limit for food supplements established by the European Commission. bdl, below detection limits

respectively, not differing significantly from each other ( $p>0.05$, Mann-Whitney $U$ test). Most of the tested products revealed $\mathrm{Hg}$ content much below the maximum allowance level set for food supplements by the European Commission (Fig. 2).

\section{Lead}

The mean $\pm \mathrm{SD}$ (median) content of $\mathrm{Pb}$ in Spirulina and Chlorella supplements was $2.6 \pm 1.9$ (2.3) and $2.6 \pm 1.3$ (2.1) and did not differ significantly ( $p>0.05$, Mann-Whitney $U$ test). Four Chlorella (40\%) and five Spirulina (30.8\%) products exceeded the maximum allowance level of $\mathrm{Pb}$ ( $3.0 \mathrm{mg} \mathrm{kg}{ }^{-1}$ ) set by the European Commission, with one Chlorella supplement exceeding it over 2-fold (Fig. 2).

\section{Rare earth elements}

The total mean \pm SD (median) content of REEs in Spirulina and Chlorella was $2.14 \pm 1.89$ (1.25) and $2.03 \pm 11.28$ (1.63) 
$\mathrm{mg} \mathrm{kg}{ }^{-1}$, respectively. A significantly higher content of LREEs was noted in both product groups $(p<0.05$, MannWhitney $U$ test) with a mean LREEs:HREEs ratio of $4: 1$. The maximum allowed REE content $\left(7.0 \mathrm{mg} \mathrm{kg}^{-1} \mathrm{dw}\right)$ was exceeded by only one Spirulina product (Table 2).

\section{Essential elements}

\section{Macroelements}

The content of macroelements in Spirulina and Chlorella food supplements is summarized in Table 3. Their mean content decreased in the order $\mathrm{K}>\mathrm{Ca}>\mathrm{P}>\mathrm{Na}>\mathrm{Mg}$ for Spirulina products and $\mathrm{K}>\mathrm{P}>\mathrm{Ca}>\mathrm{Na}>\mathrm{Mg}$ for Chlorella supplements. A significantly higher content of $\mathrm{Ca}$ was observed for Spirulina products while Chlorella displayed a greater P level. In the case of most products, consumption of the most commonly recommended daily dose of $3.0 \mathrm{~g}$ would not lead to their significant intake (Table 3). Most of the studied supplements revealed an agreement between factual and declared content of $\mathrm{Ca}, \mathrm{K}$, and $\mathrm{Mg}$ (Fig. 3).

\section{Trace elements}

The mean content of trace elements decreased in the following order: $\mathrm{Fe}>\mathrm{Mn}>\mathrm{Zn}>\mathrm{Cu}>\mathrm{Cr}>\mathrm{Co}>\mathrm{Mo}=\mathrm{Se}$ in Spirulina supplements and $\mathrm{Fe}>\mathrm{Mn}>\mathrm{Zn}>\mathrm{Cu}>\mathrm{Cr}>\mathrm{Mo}>\mathrm{Se}>\mathrm{Co}$ in Chlorella products. Their contents, which are summarized in Table 3, did not differ between Spirulina and Chlorella products, except for $\mathrm{Cu}$ levels being significantly higher in the latter. They were also mostly low when compared with AI values by assuming a daily consumption of a $3.0-\mathrm{g}$ dose. The only exception was the level of Fe which in a similar scenario would be provided at over $25 \%$ of AI on average, with some Spirulina and Chlorella supplements providing even substantially more (Table 3 ). For the majority of Spirulina products, the factual and declared content of $\mathrm{Cu}$, $\mathrm{Mn}$, and $\mathrm{Fe}$ was found to correspond very closely. In the case of Chlorella supplements, larger discrepancies were noted, particularly with respect to $\mathrm{Cu}$ content, which was found to significantly exceed the value declared on the label (Fig. 3).

\section{Discussion}

Considering the biological activities of Spirulina and Chlorella food supplements, now evidenced also on a clinical level, it is expected that the market for these products will continue to develop. Thus, it is imperative to ensure that the quality of the final product is high and safe for consumers through, e.g., implementation of a food safety management system according to ISO 22000, efficient enforcement of various food regulations, systematic monitoring of contaminant levels, and credibility of information declared on the product label (Fernández-Segovia et al. 2014; Poniedziałek et al. 2018). The present study is a comprehensive assessment of Spirulina and Chlorella food supplements registered for trade in the EU as regards levels of essential and (potentially) toxic elements.

A variable content of toxic elements was found in the investigated products. This particularly concerned $\mathrm{Al}$ whose levels notably differed between various products, reaching over $6000 \mathrm{mg} \mathrm{kg}^{-1}$ in selected ones. It has been previously reported that some microalgal food supplements can contain a high content of this element, most likely as a result of the use of aluminium chloride as a flocculant to harvest biomass (Papazi et al. 2010; Rzymski et al. 2015). Although inexpensive and efficient, such a method may contaminate the final product with $\mathrm{Al}$ at unsafe levels, exceeding maximum dietary tolerance thresholds (Rzymski et al. 2015). Despite the poor bioavailability of $\mathrm{Al}$ ingested orally, and that once absorbed most of its load is excreted readily with urine (Taylor et al. 1998), exposure to this element has greatly increased over the decades and is now estimated to reach annually as much as $11 \mathrm{~kg}$ per capita (Exley 2013). Therefore, an effort must be made to reduce its content in food, and setting a (still not established) maximum threshold level of $\mathrm{Al}$ in different foodstuffs (including food supplements) would be a beneficial step forward in this regard. Moreover, one should note that some individuals, particularly those with renal failure diseases, may be more prone to the toxic effects of $\mathrm{Al}$ due to its increased retention and consequently, bioaccumulation (Yokel and McNamara 2001). There are number of alternative methods, such as physical or biological flocculation, whose efficiency is reliable enough to be applied to the harvest of microalgal biomass (Salim et al. 2011; Vandamme et al. 2013; Choy et al. 2018), and because they do not lead to biomass contamination, their use is highly advised in the production of Spirulina and Chlorella food supplements.

Previous studies have already reported that some food supplements containing biomass (e.g., plant material) may reveal increased levels of toxic elements such as $\mathrm{Cd}$ or $\mathrm{Pb}$. This is most probably due to contamination of the ambient environment from which the biomass was originally derived, and the bioaccumulation process. Some microalgae are also known for their tolerance and uptake of toxic metals so the chemical quality of the culture medium is likely to have a profound effect on the presence of contaminants in the produced supplement. Importantly, the present study found that $\mathrm{Cd}$ and $\mathrm{Hg}$ content in studied Spirulina and Chlorella formulas was much below the maximum allowance limits set for food supplements by the EFSA. However, the Pb levels in selected products, exceeding the allowance threshold of $3.0 \mathrm{mg} \mathrm{kg}^{-1}$, are rising concerns. Microalgae sequester $\mathrm{Pb}$ preferentially over other toxic metals, and additionally, $\mathrm{Pb}$ is more environmentally abundant than $\mathrm{Cd}$ or $\mathrm{Hg}$ - contamination with this 


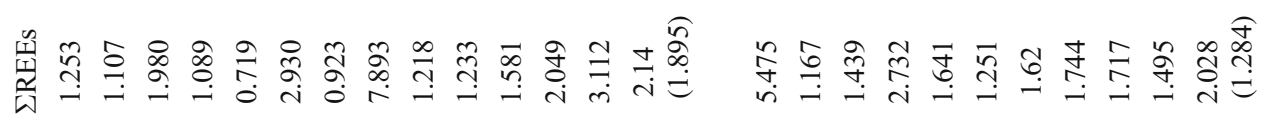

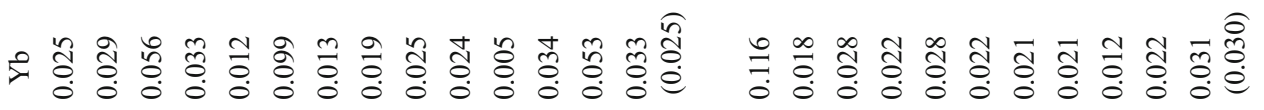

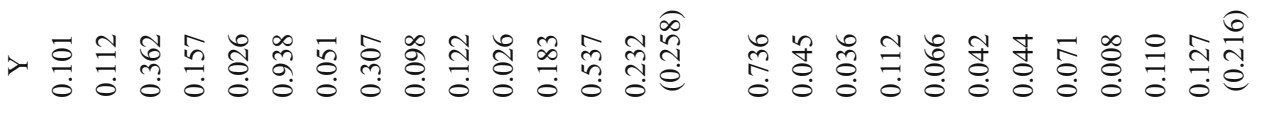

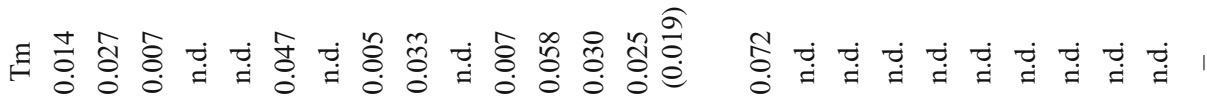

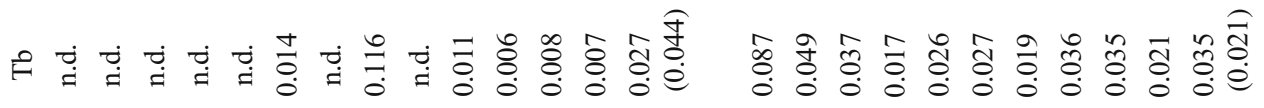

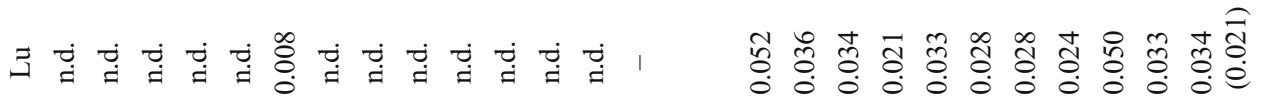

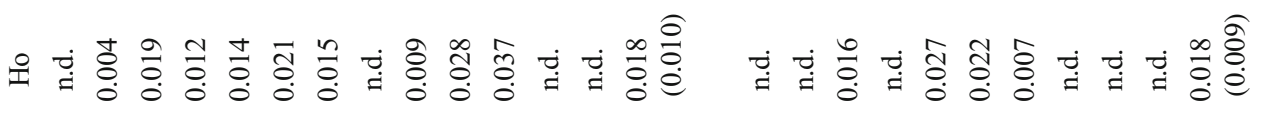

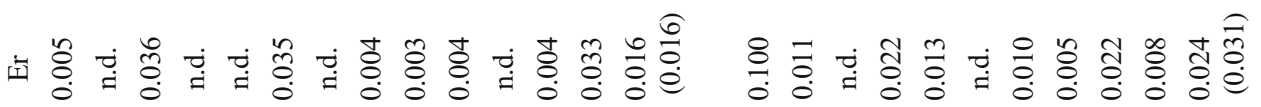

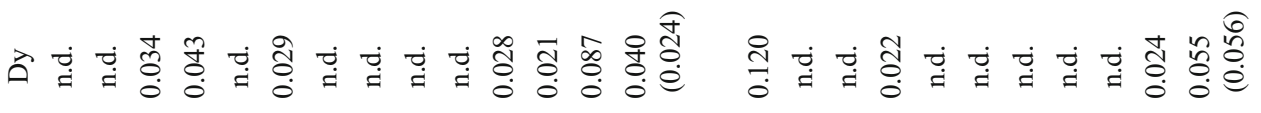

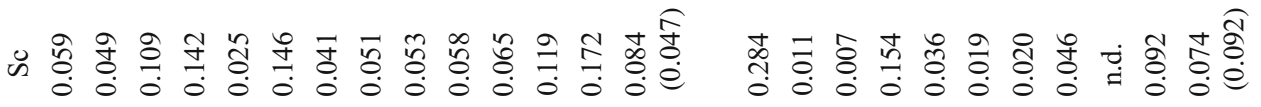

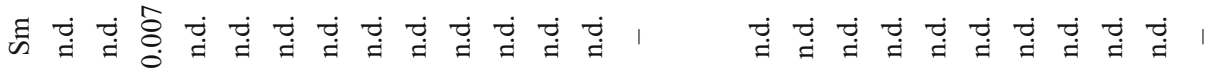

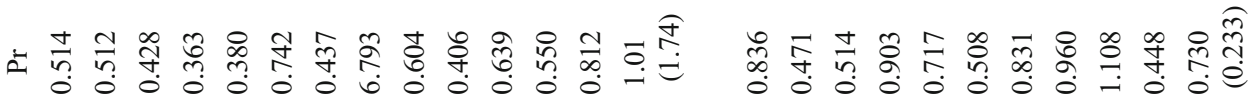

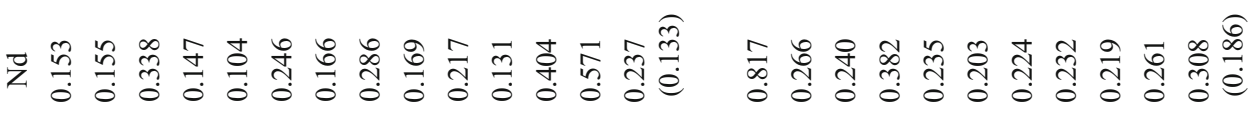

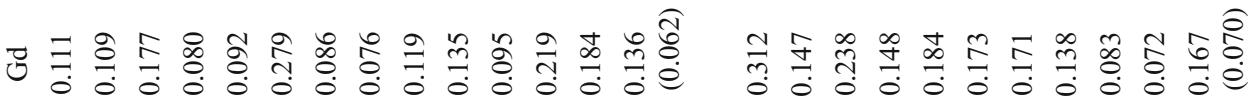

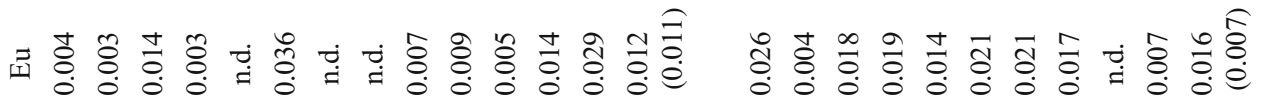

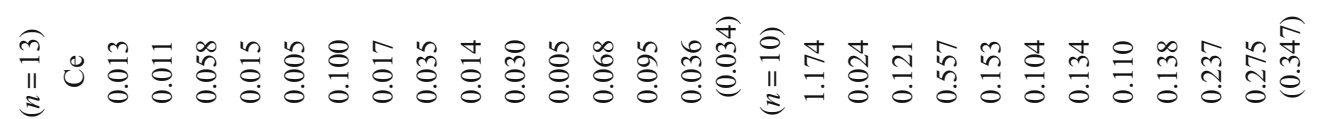

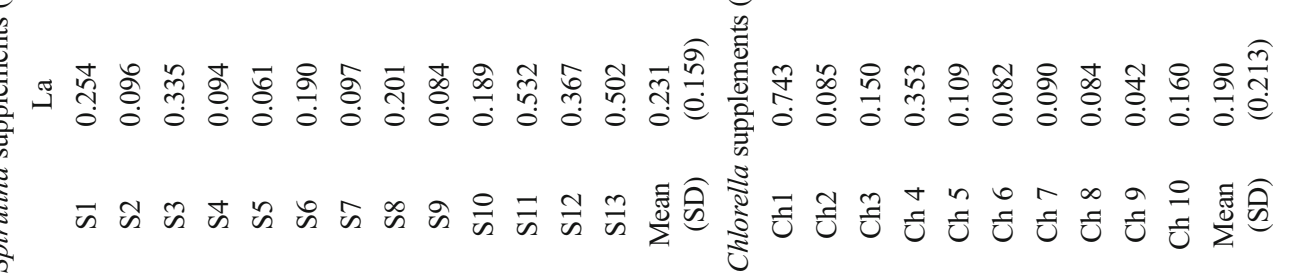


Table 3 The content of macroelements and trace elements in Spirulina $(n=13)$ and Chlorella $(n=10)$ food supplements. The reported $p$ value is for Mann-Whitney $U$ test. Percentage of Adequate Intake (\%AI) established by the European Food Safety Authority was calculated assuming a daily consumption of $3.0 \mathrm{~g}$ dose of a supplement

\begin{tabular}{|c|c|c|c|c|c|}
\hline & & Mean \pm SD (median) & Min-max & $p$ & $\% \mathrm{AI}$ \\
\hline \multirow{3}{*}{$\begin{array}{l}\text { Macroelements } \\
\mathrm{Ca}\end{array}$} & & {$\left[\mathrm{g} \mathrm{kg}^{-1}\right]$} & & & Mean (min-max) \\
\hline & Spirulina & $12.5 \pm 32.1(3.3)$ & $2.2-119.3$ & $*$ & $3.9(0.7-37.6)$ \\
\hline & Chlorella & $5.9 \pm 2.6(5.4)$ & $2.9-12.3$ & & $1.9(0.9-3.9)$ \\
\hline \multirow[t]{2}{*}{$\mathrm{P}$} & Spirulina & $11.9 \pm 14.1(8.3)$ & $6.6-58.7$ & $* * *$ & $6.5(3.6-32.0)$ \\
\hline & Chlorella & $12.4 \pm 3.8(11.8)$ & $5.0-18.6$ & & $6.7(2.7-10.1)$ \\
\hline \multirow[t]{2}{*}{$\mathrm{Mg}$} & Spirulina & $3.4 \pm 1.3(2.9)$ & $1.9-6.6$ & n.s. & $2.9(1.6-5.6)$ \\
\hline & Chlorella & $3.5 \pm 1.8(3.3)$ & $1.3-6.3$ & & $3.0(1.1-5.4)$ \\
\hline \multirow[t]{2}{*}{$\mathrm{Na}$} & Spirulina & $11.0 \pm 6.6(10.4)$ & $4.2-28.1$ & $*$ & - \\
\hline & Chlorella & $5.0 \pm 4.8(3.3)$ & $0.5-13.2$ & & - \\
\hline \multirow[t]{2}{*}{ K } & Spirulina & $15.7 \pm 2.8(16.0)$ & $8.5-20.9$ & n.s. & $1.3(0.7-1.8)$ \\
\hline & Chlorella & $14.5 \pm 4.5(12.4)$ & $9.8-23.0$ & & $1.2(0.8-2.0)$ \\
\hline \multicolumn{2}{|l|}{ Trace elements } & {$\left[\mathrm{mg} \mathrm{kg}^{-1}\right]$} & & & Mean (min-max) \\
\hline \multirow[t]{2}{*}{ Co } & Spirulina & $1.0 \pm 2.5(0.3)$ & $0.08-9.4$ & n.s. & - \\
\hline & Chlorella & $0.2 \pm 0.09(0.21)$ & $0.07-0.39$ & & - \\
\hline \multirow[t]{2}{*}{$\mathrm{Cr}$} & Spirulina & $3.6 \pm 6.3(1.6)$ & $0.6-24.4$ & n.s. & - \\
\hline & Chlorella & $2.5 \pm 1.3(2.3)$ & $1.1-4.8$ & & - \\
\hline \multirow[t]{2}{*}{$\mathrm{Cu}$} & Spirulina & $4.4 \pm 4.5(2.4)$ & $0.9-15.1$ & $* *$ & $0.8(0.2-2.8)$ \\
\hline & Chlorella & $10.1 \pm 8.8(6.3)$ & $2.6-29.4$ & & $1.9(0.5-5.5)$ \\
\hline \multirow[t]{2}{*}{$\mathrm{Fe}$} & Spirulina & $994.7 \pm 475.8(873.6)$ & $368.5-2286.6$ & n.s. & $27.1(10.0-62.3)$ \\
\hline & Chlorella & $1045.9 \pm 382.3(1121.0)$ & $438.4-1661.5$ & & $28.5(11.9-45.3)$ \\
\hline \multirow[t]{2}{*}{$\mathrm{Mn}$} & Spirulina & $45.8 \pm 25.7(36.3)$ & $26.1-109.8$ & n.s. & $4.6(2.6-11.0)$ \\
\hline & Chlorella & $53.8 \pm 14.1(51.1)$ & $24.2-74.6$ & & $5.4(2.4-7.5)$ \\
\hline \multirow[t]{2}{*}{ Mo } & Spirulina & $0.3 \pm 0.2(0.2)$ & $0.09-0.90$ & n.s. & $1.4(0.4-4.1)$ \\
\hline & Chlorella & $0.8 \pm 1.8(0.2)$ & $0.14-5.8$ & & $3.7(0.6-26.8)$ \\
\hline \multirow[t]{2}{*}{$\mathrm{Se}$} & Spirulina & $0.3 \pm 0.5(0.1)$ & $0.0-1.6$ & n.s. & $1.3(0.0-7.0)$ \\
\hline & Chlorella & $0.7 \pm 0.3(0.8)$ & $0.4-1.1$ & & $3.0(1.7-4.7)$ \\
\hline \multirow[t]{2}{*}{$\mathrm{Zn}$} & Spirulina & $23.2 \pm 13.3(19.7)$ & $9.6-61.4$ & n.s. & $0.6(0.2-1.6)$ \\
\hline & Chlorella & $28.4 \pm 16.9(23.3)$ & $11.2-73.5$ & & $0.7(0.3-1.9)$ \\
\hline
\end{tabular}

n.s. not significant $(p>0.05)$

$* p<0.05$; ** $p<0.01$; *** $p<0.001$ element of microalgal biomass is therefore more plausible (Rzymski et al. 2014). The increased contents of this metal have previously been reported in Spirulina and Chlorella supplements implicated in cases of human intoxication; extracts of which revealed a cytotoxicity in vitro (although the causative agent was not unambiguously elucidated) (Rzymski et al. 2015). An effort is required to eliminate microalgal biomass contaminated significantly with $\mathrm{Pb}$ to decrease exposure and ensure consumer safety. One should, however, note that selected multi-ingredient food supplements that contain a mixture of vitamins and minerals have been reported to contain even greater $\mathrm{Pb}$ content (Poniedziałek et al. 2018). The potential monitoring enforcement should therefore encompass not only microalgal-based formulations but all food supplements.

Previous studies have shown that some food supplements may be contaminated with the hexavalent form of $\mathrm{Cr}$ (Martone et al. 2013) which is recognized as a human carcinogen (Sun et al. 2015). Thus, it remains important to screen microalgal products to exclude such contamination and, as shown in the present study, none of the Spirulina and Chlorella products contained detectable levels of the Cr (VI) form. The As speciation analyses revealed, in turn, that content of this metalloid (if detectable) was mostly constituted of an organic form that reveals low or even no toxicity for humans (Hughes 2002). This is in line with previous observations (Hsu et al. 2001; Hedegaard et al. 2013; Rzymski et al. 2015). However, one should note that selected Spirulina and Chlorella products had detectable levels of inorganic As species, particularly the As(V) form. According to the EFSA (2014), the mean daily exposure to inorganic As in Europe varies from 0.24 to $0.38 \mu \mathrm{g} \mathrm{kg}^{-1}$ bw per day for adults, equivalent to $16.8-26.6 \mu \mathrm{g}$ of As per day for a $70-\mathrm{kg}$ adult. This considered, use of a usual $3.0 \mathrm{~g}$ dose of supplements with detected inorganic As would contribute significantly to its exposure, although one should note that in any case, the BMDL01 value would be exceeded. There are currently no 


\section{Spirulina}

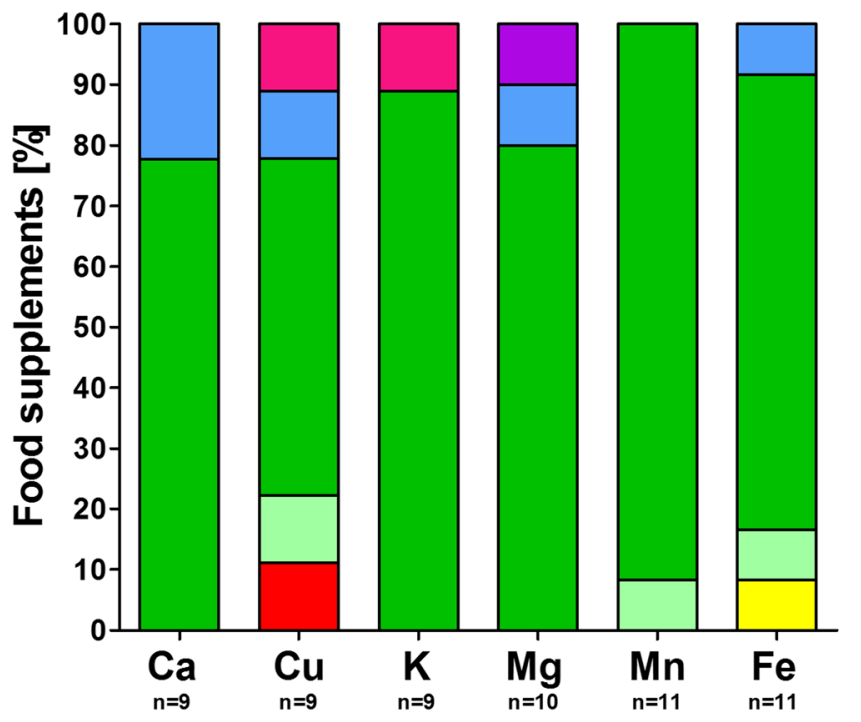

Chlorella

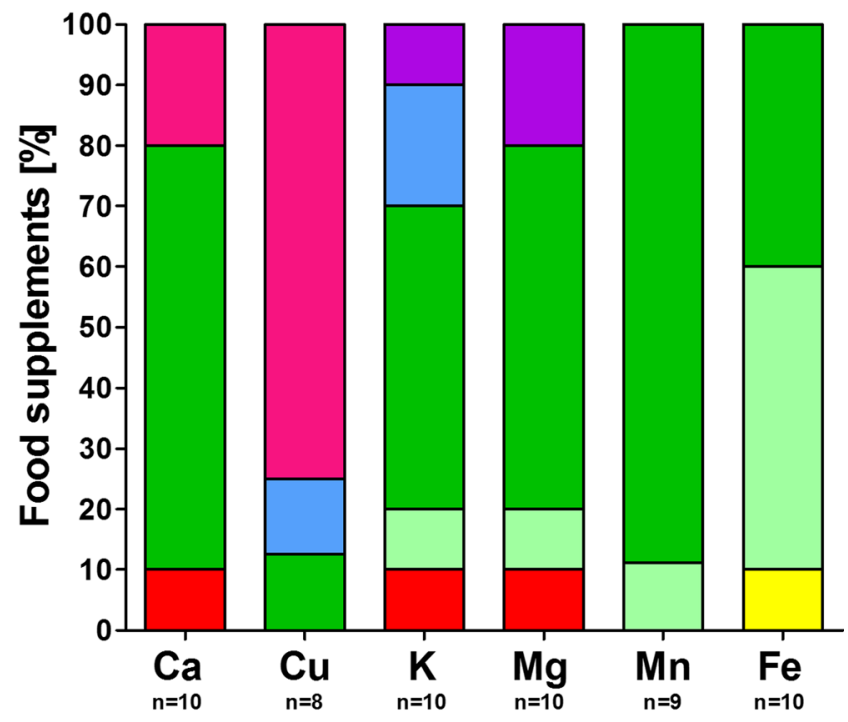

\section{Percent of declared content}

$>200 \%$

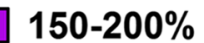

$130-150 \%$
$30-70 \%$
$<10 \%$

Fig. 3 The content of Ca, Cu, K, Mg, Mn, and Fe determined in Spirulina (left) and Chlorella (right) food supplements presented as a percentage of the content declared on the label

maximum limits for As in food supplements set in European Union - this study would suggest that the establishment of such limits would lead to the prevention of low-quality products from contaminating the market.

To the best of our knowledge, the present study is the first to analyze the level of REEs in microalgal food supplements. They represent an emerging group of pollutants whose emissions have risen over recent decades due to certain human activities (Pagano et al. 2015) resulting in increased human exposure via different routes (Poniedziałek et al. 2017). The outcomes of these exposures are yet to be fully explored, although selected REEs reveal cytotoxicity and have been potentially linked to anti-testicular effects, male sterility, hypertension in females, reduced IQ, and neurological alterations in children (Zhu et al. 1996; Marzec-Wróblewska et al. 2015; Wang et al. 2017; Gwenzi et al. 2018). Diet may constitute an important route of human exposure to REEs, and various foodstuffs such as mushrooms or vegetables already have been reported to exceed the maximum $0.7 \mathrm{mg} \mathrm{kg}^{-1}$ fresh weight (7.0 mg kg-1 dry weight) threshold limit, set so far only in China (SAC 2012; Li et al. 2013; Rzymski et al. 2017; Siwulski et al. 2017; Zhuang et al. 2017). Interestingly, some REEs, namely $\mathrm{Ce}, \mathrm{Gd}, \mathrm{La}$, and $\mathrm{Sc}$, have been reported to increase the growth of some microalgae and their content of lutein, violaxanthin, $\beta$-carotene, and chlorophylls (Goecke et al. 2017). Microalgae from the Arthrospira and Chlorella genera were also experimentally shown to bioconcentrate some REEs such as Ce or Nd (Sadovsky et al. 2016; Kücüker et al. 2017). In the present study, all studied microalgal food supplements, except for one product based on Spirulina (exceeding maximum allowance limit) and one based on Chlorella (reaching 78\% of the limit), were characterized by a relatively low content of REEs. The highest share was represented by light REEs (with Pr reaching the highest mean content in Spirulina and Chlorella products) which are known to accumulate to a greater extent in the human body (Wei et al. 2013; Hao et al. 2015). All in all, the findings of the present study indicate that microalgal food supplements, with certain exceptions, do not represent a significant dietary source of REEs.

While Spirulina and Chlorella food products are known to contain a high content of proteins, polyunsaturated fatty acids, and various pigments, the nutritional value of their mineral content, both macro- and trace elements, is relatively low, particularly if one considers the most commonly recommended dose of $3.0 \mathrm{~g}$ daily. In this regard, they cannot compete with a number of other commonly eaten food products such as vegetables or fruits. On the other hand, the Tolerable Upper Intake Level (UL) and Safety Upper Level (SUL)/Guidance Level (GL) as set respectively by the EFSA (2017b) and the Expert Group on Vitamins and Minerals (2003) were not exceeded for any essential element considered by this study. This is an important finding as food supplements should only serve as an accessory source of nutrients in a balanced diet and 
not as their substitution. An excessive intake of minerals can lead to various adverse effects including neurotoxic responses $(\mathrm{Mn})$, cardiotoxicity $(\mathrm{Co})$, gastrointestinal symptoms $(\mathrm{Cu}, \mathrm{Fe}$, $\mathrm{K}, \mathrm{Mg}$ ), altered immune function $(\mathrm{Zn})$, or unwanted cardiovascular events (Ca) (Verkaik-Kloosterman et al. 2012). One should note, however, that the studied Spirulina and Chlorella food supplements served as a rich source of $\mathrm{Fe}$. On average, daily supplementation with the most commonly recommended dose of $3.0 \mathrm{~g}$ would constitute $25 \%$ of AI with some Spirulina and Chlorella products reaching over 60 and $40 \%$ of AI, respectively. As found in previous studies, bioavailability of Fe from Spirulina biomass (in which it is mostly present as ferrihydrite) is lower than that of ferrous sulfate, often used in mineral food supplements, but higher than that in whole wheat (Kapoor and Mehta 1992; Perfiliev et al. 2018). However, in the case of Fe-fortified Spirulina, mineral bioavailability can be even higher than that from meat products (Puyfoulhoux et al. 2001). Considering the Fe content in microalgal food supplement and the fact that they can contain bioavailable forms of vitamin $\mathrm{B}_{12}$ (Nakano et al. 2010; De et al. 2011; Merchant et al. 2015), these products are potentially of high interest to individuals on vegetarian diets which are becoming increasingly popular in different populations (Dinu et al. 2017). It would be therefore interesting to conduct a clinical trial investigating whether Spirulina supplementation may have a beneficial effect on Fe burden. Although one recent study has shown that such intervention unexpectedly decreased the concentration of serum Fe (Suliburska et al. 2016), one should note that this parameter alone, without assessing a number of other biochemical markers (e.g., transferrin, ferritin, hemoglobin, hepcidin, etc.), is not sufficient to evaluate Fe status in humans (Rzymski and Ganz 2018).

The nutritional value of the food supplement declared on the container label is an important factor in assisting the consumers' decision-making processes when purchasing a product. A worrisome finding of some recent investigations is that actual declared levels of ingredients in various food supplements does not agree with their actual content, with the majority of investigated products being far from meeting the acceptable margin (Brandon et al. 2014; Niedzielski et al. 2016; Verkaik-Kloosterman et al. 2017; Poniedziałek et al. 2018). Contrary to this, most of the studied products revealed good agreement in this respect. This particularly concerned the content of $\mathrm{Ca}, \mathrm{K}, \mathrm{Mg}, \mathrm{Mn}$, and $\mathrm{Fe}$ in Spirulina supplements. Some discrepancies were found for some Chlorella products with most of those studied having a significantly higher content of $\mathrm{Cu}$ than that declared on the label. Although the origins of such an increased content of $\mathrm{Cu}$ levels can only be hypothesized, one should note that $\mathrm{Cu}$ compounds can be used in Chlorella cultures as selective inhibitors of some grazing rotifers which can occur in open pond cultivation systems and cause a significant economic loss (Pradeep et al. 2015; Day et al. 2017); such an application may significantly alter $\mathrm{Cu}$ content in the final food product.

\section{Conclusion}

In summary, the study screened the content of minerals and toxic elements in selected Spirulina and Chlorella food supplements registered on the European market and originating from Asia, North America, and Europe. Considering the most commonly recommended daily dose of $3 \mathrm{~g}$, the use of such products would rather not contribute significantly to mineral intake, except for Fe whose levels were found to be high in both Spirulina and Chlorella formulas. An important finding is that most of the studied products revealed a good agreement between declared and factual content of elements. The microalgal food supplements appear not to contribute significantly to dietary intake of REEs. Even though some of the products screened by this study revealed increased levels of toxic metals such as $\mathrm{Al}$ or $\mathrm{Pb}$, this should by no means be a reason to disregard the very promising bioactive properties of Arthrospira or Chlorella. It is rather an indication that the quality control of such products should be strengthened so that only those microalgal food supplements which ensure consumer safety can reach the market.

\section{Compliance with ethical standards}

Conflict of interest The authors declare that they have no conflict of interest.

Open Access This article is distributed under the terms of the Creative Commons Attribution 4.0 International License (http:// creativecommons.org/licenses/by/4.0/), which permits unrestricted use, distribution, and reproduction in any medium, provided you give appropriate credit to the original author(s) and the source, provide a link to the Creative Commons license, and indicate if changes were made.

\section{References}

Al-Dhabi NA (2013) Heavy metal analysis in commercial Spirulina products for human consumption. Saudi J Biol Sci 20:383-388

Bailey RL, Gahche JJ, Miller PE, Thomas PR, Dwyer JT (2013) Why US adults use food supplements. JAMA Intern Med 173:355-361

Brandon EF, Bakker MI, Kramer E, Bouwmeester H, Zuidema T, Alewijn M (2014) Bioaccessibility of vitamin A, vitamin C and folic acid from dietary supplements, fortified food and infant formula. Int $\mathrm{J}$ Food Sci Nutr 65:426-435

Buono S, Langellotti AL, Martello A, Rinna F, Fogliano V (2014) Functional ingredients from microalgae. Food Funct 58:1669-1685

Choy SY, Prasad KMN, Wu TY, Raghunandan ME, Phang S-M, Juan JC, Ramanan RN (2018) Separation of Chlorella biomass from culture medium by flocculation with rice starch. Algal Res 30:162-172

Commission Regulation (EC) No 629/2008 of 2 July 2008 amending Regulation (EC) No 1881/2006 setting maximum levels for certain contaminants in foodstuffs 
Day JG, Gong Y, Hu Q (2017) Microzooplanktonic grazers-a potentially devastating threat to the commercial success of microalgal mass culture. Algal Res 27:356-365

de la Jara A, Ruano-Rodriguez C, Polifrone M, Assunçao P, BritoCasillas Y, Wägner AM, Serra-Majem L (2018) Impact of dietary Arthrospira (Spirulina) biomass consumption on human health: main health targets and systematic review. J Appl Phycol 30: 2403-2423

De M, Halder A, Chakraborty T, Das U, Paul S, De A, Banerjee J, Chatterjee T, De S (2011) Incidence of anemia and effect of nutritional supplementation on women in rural and tribal populations of eastern and northeastern India. Hematology 16:190-192

Dinu M, Abbate R, Gensini GF, Casini A, Sofi F (2017) Vegetarian, vegan diets and multiple health outcomes: a systematic review with meta-analysis of observational studies. Crit Rev Food Sci Nutr 57: 3640-3649

Ebrahimi-Mameghani M, Sadeghi Z, Abbasalizad Farhangi M, VaghefMehrabany E, Aliashrafi S (2017) Glucose homeostasis, insulin resistance and inflammatory biomarkers in patients with nonalcoholic fatty liver disease: beneficial effects of supplementation with microalgae Chlorella vulgaris: a double-blind placebo-controlled randomized clinical trial. Clin Nutr 36:1001-1006

EFSA (2008) Safety of aluminium from dietary intake - Scientific opinion of the Panel on Food Additives, Flavourings, Processing Aids and Food Contact Materials (AFC). EFSA J 754:1-34

EFSA (2009) Scientific opinion on arsenic in food. EFSA Panel on Contaminants in the Food Chain (CONTAM). EFSA J 7:1351

EFSA (2014) Dietary exposure to inorganic arsenic in the European population. EFSA J 12:3597

EFSA (2015) Scientific opinion on the risks to public health related to the presence of nickel in food and drinking water. EFSA J 13:4002

EFSA (2017a) Dietary reference values for nutrients. Summary report. EFSA supporting publication. https://doi.org/10.2903/sp.efsa.2017. e15121

EFSA (2017b) Overview on Tolerable Upper Intake Levels as derived by the Scientific Committee on Food (SCF) and the EFSA Panel on Dietetic Products, Nutrition and Allergies (NDA) https://www.efsa. europa.eu/sites/default/files/assets/UL_Summary_tables.pdf. Accessed 21 October 2018

Exley C (2013) Human exposure to aluminium. Environ Sci Process Impacts 15:1807-1816

Fernández-Segovia I, Pérez-Llácer A, Peidro B, Fuentes A (2014) Implementation of a food safety management system according to ISO 22000 in the food supplement industry: a case study. Food Control 43:28-34

García JL, de Vicente M, Galán B (2017) Microalgae, old sustainable food and fashion nutraceuticals. Microb Biotechnol 10:1017-1024

Goecke F, Vítová M, Lukavský J, Nedbalová L, Řezanka T, Zachleder V (2017) Effects of rare earth elements on growth rate, lipids, fatty acids and pigments in microalgae. Phycol Res 65:226-234

Gwenzi W, Mangori L, Danha C, Chaukura N, Dunjana N, Sanganyado E (2018) Sources, behaviour, and environmental and human health risks of high-technology rare earth elements as emerging contaminants. Sci Total Environ 636:299-313

Hao Z, Li Y, Li H, Wei B, Liao X, Liang T, Yu J (2015) Levels of rare earth elements, heavy metals and uranium in a population living in Baiyun Obo, Inner Mongolia, China: a pilot study. Chemosphere 128:161-170

Hedegaard R, Rokkjær I, Sloth JJ (2013) Total and inorganic arsenic in dietary supplements based on herbs, other botanicals and algae - a possible contributor to inorganic arsenic exposure. Anal Bioanal Chem 405:4429-4435

Hirayama F, Lee AH, Binns CW, Watanabe F, Ogawa T (2008) Food supplementation by older adults in Japan. Asia Pac J Clin Nutr 17: 280-284
Hsu Y-M, Hwang J-M, Yeh T-R (2001) Inorganic elements determination for algae/Spirulina food marketed in Taiwan. J Food Drug Anal 9: 178-182

Hughes MF (2002) Arsenic toxicity and potential mechanisms of action. Toxicol Lett 133:1-16

JECFA (2012) Safety evaluation of certain food additives/prepared by the seventy fourth meeting of the Joint FAO/WHO Expert Committee on Food Additives (JECFA) WHO Food Additives Series, vol 65

Johnson M, Hassinger L, Davis J, Devor ST, DiSilvestro RA (2016) A randomized, double blind, placebo controlled study of Spirulina supplementation on indices of mental and physical fatigue in men. Int J Food Sci Nutr 67:203-206

Juszkiewicz A, Basta P, Petriczko E, Machaliński B, Trzeciak J, Łuczkowska K, Skarpańska-Stejnborn A (2018) An attempt to induce an immunomodulatory effect in rowers with Spirulina extract. J Int Soc Sports Nutr 15:9

Kapoor R, Mehta U (1992) Iron bioavailability from Spirulina platensis, whole egg and whole wheat. Indian J Exp Biol 30:904-907

Kennedy J (2005) Herb and supplement use in the US adult population. Clin Ther 27:1847-1858

Kim S, Kim J, Lim Y, Kim YJ, Kim JY, Kwon O (2016) A dietary cholesterol challenge study to assess Chlorella supplementation in maintaining healthy lipid levels in adults: a double-blinded, randomized, placebo-controlled study. Nutr J 15:54

Kücüker MA, Wieczorek N, Kuchta K, Copty NK (2017) Biosorption of neodymium on Chlorella vulgaris in aqueous solution obtained from hard disk drive magnets. PLoS One 12:e0175255

Lee AN, Werth VP (2004) Activation of autoimmunity following use of immunostimulatory herbal supplements. Arch Dermatol 140:723727

Li X, Chen Z, Chen Z, Zhang Y (2013) A human health risk assessment of rare earth elements in soil and vegetables from a mining area in Fujian Province, Southeast China. Chemosphere 93:1240-1246

Manali KM, Arunraj R, Kumar T, Ramya M (2017) Detection of microcystin producing cyanobacteria in Spirulina dietary supplements using multiplex HRM quantitative PCR. J Appl Phycol 29: $1279-1286$

Martone N, Rahman GM, Pamuku M, Kingston HM (2013) Determination of chromium species in food supplements using speciated isotope dilution mass spectrometry with mass balance. $\mathrm{J}$ Agric Food Chem 61:9966-9976

Marzec-Wróblewska U, Kamiński P, Lakota P, Ludwikowski G, Szymański M, Wasilow K, Stuczyński T, Buciński A, Jerzak L (2015) Determination of rare earth elements in human sperm and association with semen quality. Arch Environ Contam Toxicol 69: 191-201

Merchant RE, Phillips TW, Udani J (2015) Nutritional supplementation with Chlorella pyrenoidosa lowers serum methylmalonic acid in vegans and vegetarians with a suspected vitamin $\mathrm{B}_{12}$ deficiency. $\mathrm{J}$ Med Food 18:1357-1362

Nakano S, Takekoshi H, Nakano M (2010) Chlorella pyrenoidosa supplementation reduces the risk of anemia, proteinuria and edema in pregnant women. Plant Foods Hum Nutr 65:25-30

Niedzielski P, Mleczek M, Magdziak Z, Siwulski M, Kozak L (2013) Selected arsenic species: As (III), As(V) and dimethylarsenic acid (DMAA) in Xerocomus badius fruiting bodies. Food Chem 141: 3571-3577

Niedzielski P, Rudnicka M, Wachelka M, Kozak L, Rzany M, Wozniak M, Kaskow Z (2016) Selenium species in selenium fortified food supplements. Food Chem 190:454-459

Nielsen CH, Balachandran P, Christensen O, Pugh ND, Tamta H, Sufka KJ, Wu X, Walsted A, Schjørring-Thyssen M, Enevold C, Pasco DS (2010) Enhancement of natural killer cell activity in healthy subjects by Immulina ${ }^{\circledR}$, a Spirulina extract enriched for Braun-type lipoproteins. Planta Med 76:1802-1808 
Pagano G, Aliberti F, Guida M, Oral R, Siciliano A, Trifuoggi M, Tommasi F (2015) Rare earth elements in human and animal health: state of art and research priorities. Environ Res 142:215-220

Panahi Y, Mostafazadeh B, Abrishami A, Saadat A, Beiraghdar F, Tavana S, Pishgoo B, Parvin S, Sahebkar A (2013) Investigation of the effects of Chlorella vulgaris supplementation on the modulation of oxidative stress in apparently healthy smokers. Clin Lab 59:579587

Panahi Y, Badeli R, Karami GR, Badeli Z, Sahebkar A (2015) A randomized controlled trial of 6-week Chlorella vulgaris supplementation in patients with major depressive disorder. Complement Ther Med 23:598-602

Panahi Y, Darvishi B, Jowzi N, Beiraghdar F, Sahebkar A (2016) Chlorella vulgaris: a multifunctional dietary supplement with diverse medicinal properties. Curr Pharm Des 22:164-173

Papazi A, Makridis P, Divanach P (2010) Harvesting Chlorella minutissima using cell coagulants. J Appl Phycol 22:349-355

Perfiliev YD, Tambiev AK, Konnychev MA, Skalny AV, Lobakova ES, Kirpichnikov MP (2018) Mössbauer spectroscopic study of transformations of iron species by the cyanobacterium Arthrospira platensis (formerly Spirulina platensis). J Trace Elem Med Biol 48:105-110

Poniedziałek B, Rzymski P, Pięt M, Niedzielski P, Mleczek M, Wilczak M, Rzymski P (2017) Rare-earth elements in human colostrum milk. Environ Sci Pollut Res 24:26148-26154

Poniedziałek B, Niedzielski P, Kozak L, Rzymski P, Wachelka M, Rzymska I, Karczewski J, Rzymski P (2018) Monitoring of essential and toxic elements in multi-ingredient food supplements produced in European Union. Journal of Consumer Protection and Food Safety 13(1):41-48

Pradeep V, Van Ginkel SW, Park S, Igou T, Yi C, Fu H, Johnston R, Snell T, Chen Y (2015) Use of copper to selectively inhibit Brachionus calyciflorus (predator) growth in Chlorella kessleri (prey) mass cultures for algae biodiesel production. Int J Mol Sci 16:20674-20684

Pulz O, Gross W (2004) Valuable products from biotechnology of microalgae. Appl Microbiol Biotechnol 65:635-648

Puyfoulhoux G, Rouanet JM, Besançon P, Baroux B, Baccou JC, Caporiccio B (2001) Iron availability from iron-fortified Spirulina by an in vitro digestion/Caco-2 cell culture model. J Agric Food Chem 49:1625-1629

Roy-Lachapelle A, Solliec M, Bouchard MF, Sauvé S (2017) Detection of cyanotoxins in algae dietary supplements. Toxins 9

Rzymski P, Ganz T (2018) Comment on "Serum Hepcidin and Soluble Transferrin Receptor in the Assessment of Iron Metabolism in Children on a Vegetarian Diet". Biol Trace Elem Res 185:252-254

Rzymski P, Jaśkiewicz M (2017) Microalgal food supplements from the perspective of Polish consumers: patterns of use, adverse events, and beneficial effects. J Appl Phycol 29:1841-1850

Rzymski P, Niedzielski P, Poniedziałek B, Karczewski J (2014) Biosorption of toxic metals using freely suspended Microcystis aeruginosa biomass. Centr Eur J Chem 12:1232-1238

Rzymski P, Niedzielski P, Kaczmarek N, Jurczak T, Klimaszyk P (2015) The multidisciplinary approach to safety and toxicity assessment of microalgae-based food supplements following clinical cases of poisoning. Harmful Algae 46:34-42

Rzymski P, Mleczek M, Siwulski M, Jasińska A, Budka A, Niedzielski P, Kalac P, Gasecka M, Budzyńska S (2017) Multielemental analysis of fruit bodies of three cultivated commercial Agaricus species. J Food Compos Anal 59:170-178

SAC 2012 Standardization Administration of the People's Republic of China. Maximum levels of contaminants in foods; GB 2762-2012 J Verbrauch Lebensm. http:/www.cirs-group.com/uploads/soft/ 140901/GB_2762-2012_Food_Safety_National_Standard_for Maximum_levels_of_contaminants_in_foods.pdf. Accessed 21 October 2018
Sadovsky D, Brenner A, Astrachan B, Asaf B, Gonen R (2016) Biosorption potential of cerium ions using Spirulina biomass. J Rare Earths 34:644-652

Salim S, Bosma R, Vermuë MH, Wijffels RH (2011) Harvesting of microalgae by bio-flocculation. J Appl Phycol 23:849-855

Siwulski M, Mleczek M, Rzymski P, Budka A, Jasińska A, Niedzielski P, Kalac P, Gąsecka M, Budzyńska S, Mikołajczak P (2017) Screening the multi-element content of Pleurotus mushroom species using inductively coupled plasma optical emission spectrometer (ICPOES). Food Anal Methods 10:487-496

Suliburska J, Szulińska M, Tinkov AA, Bogdański P (2016) Effect of Spirulina maxima supplementation on calcium, magnesium, iron, and zinc status in obese patients with treated hypertension. Biol Trace Elem Res 173:1-6

Sun H, Brocato J, Costa M (2015) Oral chromium exposure and toxicity. Curr Environ Health Rep 2:295-303

Taylor GA, Moore PB, Ferrier IN, Tyrer SP, Edwardson JA (1998) Gastrointestinal absorption of aluminium and citrate in man. J Inorg Biochem 69:165-169

The Expert Group on Vitamins and Minerals (2003) Safe upper levels for vitamins and minerals. Food Standards Agency Publications, London

Vandamme D, Foubert I, Muylaert K (2013) Flocculation as a low-cost method for harvesting microalgae for bulk biomass production. Trends Biotechnol 31:233-239

Verkaik-Kloosterman J, McCann MT, Hoekstra J, Verhagen H (2012) Vitamins and minerals: issues associated with too low and too high population intakes. Food Nutr Res 56:5728

Verkaik-Kloosterman J, Seves SM, Ocké MC (2017) Vitamin D concentrations in fortified foods and dietary supplements intended for infants: implications for vitamin D intake. Food Chem 221:629-635

Vichi S, Lavorini P, Funari E, Scardala S, Testai E (2012) Contamination by Microcystis and microcystins of blue-green algae food supplements (BGAS) on the Italian market and possible risk for the exposed population. Food Chem Toxicol 50:4493-4499

Wang B, Yan L, Huo W, Lu Q, Cheng Z, Zhang J, Li Z (2017) Rare earth elements and hypertension risk among housewives: a pilot study in Shanxi Province, China. Environ Pollut 220:837-842

Wei B, Li Y, Li H, Yu J, Ye B, Liang T (2013) Rare earth elements in human hair from a mining area of China. Ecotoxicol Environ Saf 96: $118-123$

Wells ML, Potin P, Craigie JS, Raven JA, Merchant SS, Helliwell KE, Smith AG, Camire ME, Brawley SH (2016) Algae as nutritional and functional food sources: revisiting our understanding. J Appl Phycol 29:949-982

Yokel RA, McNamara PJ (2001) Aluminium toxicokinetics: an updated minireview. Pharmacol Toxicol 88:159-167

Zeinalian R, Farhangi MA, Shariat A, Saghafi-Asl M (2017) The effects of Spirulina platensis on anthropometric indices, appetite, lipid profile and serum vascular endothelial growth factor (VEGF) in obese individuals: a randomized double blinded placebo controlled trial. BMC Complement Altern Med 17:225

Zhu WF, Xu SQ, Zhang H, Shao PP, Wu DS, Yang WJ (1996) Investigation of children intelligence quotient in REE mining area: bio-efffect study of REE mining area of South Jiangxi. Chin Sci Bull 41:914-916

Zhuang M, Zhao J, Li S, Liu D, Wang K, Xiao P, Yu L, Jiang Y, Song J, Zhou J, Wang L, Chu Z (2017) Concentrations and health risk assessment of rare earth elements in vegetables from mining area in Shandong, China. Chemosphere 168:578-582

Publisher's note Springer Nature remains neutral with regard to jurisdictional claims in published maps and institutional affiliations. 